\title{
Zemřel slovenský znalec církevních dějin a historie Trnavské univerzity
}

Jozef Šimončič se narodil v roce 1928 v Dechticích v okrese Trnava. I když jeho rodiče nebyli př́liš majetní, přesto měl možnost studovat na gymnáziu, nejprve na církevním v Trnavě a potom v Pieštanech. V roce 1944 se rozhodl vstoupit do jezuitského řádu; jistě s vřelým souhlasem rodičů, kteří nepochybně ne náhodou dali jeho mladšímu bratrovi jméno po zakladateli Tovaryšstva Ježíšova - Ignác. V Ružomberku během noviciátu zažil těžké chvíle, když se přes město v roce 1944 převalily válečné boje a jezuitský noviciát se dokonce musel odtud na čas přestěhovat. Po povinném dvouletém noviciátu a maturitě se odebral na filozofická studia do Děčína, kde jezuité spravovali Filozofický ústav. Jak lze předvídat, ani započetí filozofických studií u jezuitů v roce 1948 nemělo skýtat do budoucna př́liš optimismu. Tak se také stalo. V rámci Akce $\mathrm{K}$ bylo děčínské učiliště zrušeno a jeho frekventanti internováni v nedalekém Bohosudově. Jozef Šimončič se místo vytoužených studií ocitl na vojně - u neblaze proslulých „pétépákư“ - konkrétně u 54. pomocného technického praporu v Komárně. Během nelehkých čtyř let neradostné vojny kromě jiného pracoval v Podbořanech, nebo stavěl nové bytovky v Banské Bystrici. Ve stavebním podniku Stavoindustria Bratislava pracoval krátce jako brigádník i po návratu z vojny, než se mohl odebrat do svému srdci blízké Trnavy. Pracovní nasazení u PTP se podepsalo nejen na jeho zdravotním stavu, ale systematický nátlak StB a perzekuce ho donutily i vystoupit z Tovaryšstva Ježíšova. Následky nuceného pobytu u „pétépákư“ si nesl po celý život, ale alespoň mu zdravotní potíže umožnily opakované léčebné pobyty ve Vysokých Tatrách, které si bytostně zamiloval. Vím, jak těžce nesl nejen přemíru turistického ruchu v těchto krásných horách, ale zejména devastaci tatranských lesů při orkánu v listopadu roku 2004. Obával se (bohužel právem), že jejich plné obnovy se už nedožije...

Po návratu do civilu se Jozef Šimončič nejprve marně ucházel o místo knihovníka v bratislavské Univerzitní knihovně, ale potom se mu naskytla př́ležitost využí svého zaujetí pro historii a od 1. listopadu 1954 nastoupil jako archiváŕ do Archivu města Trnavy. Jak př́iznačné - archivy se v předlistopadovém Československu stávaly často útočištěm „nepohodlných" osob, kterým ovšem př́mý kontakt s prameny skýtal obrovský zdroj inspirace a podnětů $\mathrm{k}$ vědecké práci. $\mathrm{V}$ tomto ohledu shledávám paralely životních osudů Jozefa Šimončiče a jiného velkého znalce církevních dějin raného novověku - moravského Rudolfa Zubera, který rovněž velkou část svého aktivního života prožil jako archivář v Javorníku.

Při zaměstnání bylo Šimončičovi umožněno vystudovat Vysokou školu pedagogickou; začal v oboru slovenština a poté se přiklonil k dějepisu. Po správní reorganizaci v roce 1960 byl pověřen řízením nově vzniklého Okresního archivu v Trnavě. Uvolnění v šedesátých letech mu umožnilo i větši veřejné aktivity, od roku 1964 byl napřs. tajemníkem Slovenské historické společnosti v Trnavě a mohl navštívit v rámci studijních pobytů i zahraničí (byt' jen tehdy spřátelené země). V roce 1971složil na Filozofické fakultě Univerzity Komenského v Bratislavě rigorózní zkoušky a získal titul PhDr. a v témže roce začal v Historickém 
ústavu SAV u PhDr. Jána Tibenského, DrSc., aspirantská studia (tzn. cosi obdobného jako současná doktorská studia) na téma Ohlasy Francouzské revoluce na Slovensku. Práci obhájil v roce 1978 a zveřejnění tiskem mu vyneslo cenu vydavatelství Slovenský spisovatel. Od roku 1979 přednášel na Pedagogické fakultě v Trnavě regionalistiku a metodologii vlastivědy a v osmdesátých letech mohl studijně vycestovat i do Jugoslávie, Polska a v roce 1988 také do Paříže, kde mohl uplatnit i svou dobrou znalost francouzštiny.

Ačkoliv jeho bádání a studie o ohlasu Francouzské revoluce na Slovensku se dočkaly př́iznivého ocenění, naplno uplatnit svůj bytostný zájem o duchovní dějiny směl Jozef Šimončič až po roce 1989. Své znalosti a kontakty se členy jezuitského řádu využil hned v roce 1990, kdy v kanadské Cambridgi vyšly velmi pěkné Dejiny Spoločnosti Ježíšovej na Slovensku, na nichž se podílel jak autorsky, tak redakčně. V roce 1991 konečně vycestoval i do Říma a studoval v tamním jezuitském centrálním archivu - Archivum Romanum Societatis Iesu (ARSI), což potom zopakoval i v dalších letech. V roce 1992 byl odvolán z funkce ředitele archivu a začal přednášet na obnovené Trnavské univerzitě pomocné vědy historické, slovenské dějiny v raném novověku, dějiny reformace a rekatolizace na Slovensku a samozřejmě i historii trnavské univerzity. V roce 1994 se habilitoval a o čtyři roky později získal i profesuru. Na jezuity nezapomínal, např. v roce 1995 se zúčastnil v Brně konference na téma Brno na konci třicetileté války, kde přednesl referát o Georgiu Rumerovi, SJ, prvním českém jezuitském provinciálovi po roce 1623. Nezapomínal prritom ani na svůj zájem o stopy Francouzské revoluce a od roku 1995 byl členem The International Napoleonic Society.

Zejména se ale zasloužil o povznesení jména Trnavské univerzity a o založení tamního Ústavu dejín, jehož se stal prvním ředitelem (od roku 2002). Redigoval kromě jiného (spolu s Danielem Škovierem a Vladimírem Rábikem) publikaci Trnavská univerzita v dokumentoch (2002), zabýval se osobností zakladatele Trnavské univerzity Petra Pázmáně a inicioval edici historických studií Fons Tyrnaviensis. Pozoruhodnou intelektuální aktivitu vykazoval bezmála až do posledních chvil. Jeho celoživotní dílo vzpomněli žáci a prátelé u př́ležitosti jeho devadesátin, kdy vyšla publikace redigovaná jeho žačkou a následovnicí ve výzkumu univerzitních dějin Henriettou Žažovou.

Všichni blízcí a přátelé vzpomínají na Jozefa Šimončiče jako na duchovního člověka, po celý život upřímně věřícího i oddaného své historické práci. Ačkoliv mohl jako pedagog působit jen relativně nedlouhou dobu na sklonku života, vychoval žáky, kteří pokračují v jeho díle. Jozef Šimončič zemřel v požehnaném věku 21. 11. 2020 v Trnavě. 